\title{
MULTI-SCALE MODEL ELABORATION FOR CREDITWORTHINESS DIAGNOSTICS OF EXPORT PRODUCTION ENTERPRISES OF THE AGRICULTURAL TRADE MARKET
}

\author{
Olena Sergienko \\ Department of Business, Trade and Products Expertise ${ }^{l}$ \\ serhelenka@gmail.com \\ Olena Shapran \\ Department of Economics and Marketing \\ elena.shapran82@gmail.com \\ Oleksandr Bilotserkivskyi \\ Department of Business, Trade and Products Expertise ${ }^{1}$ \\ abelocerk@gmail.com \\ Iryna Alieksieieva \\ Department of Management and Taxation ${ }^{1}$ \\ Alexiren2906@gmail.com \\ ${ }^{1}$ National Technical University «Kharkiv Polytechnic Institute» \\ 2 Kyrpychova str., Kharkiv, Ukraine, 61002
}

\begin{abstract}
The methodology for the agrarian enterprises' creditworthiness diagnostic has been developed and implemented, and has allowed to solve the following objectives: conducting of observations and evaluating of financially-economic indicators, classification of enterprises by the level of creditworthiness, distinction and identification enterprises according to the level of creditworthiness and assessing the differences between classes by creditworthiness, with taking into account the sizes of enterprises. Based on the use of the complex of multidimensional analytical methods, the differences are defined under either one-dimensional evaluation system (by creditworthiness and size) or a two-level assessment of the joint cross impact of factors on creditworthiness.

The proposed four-step technology for diagnosing of the agrarian enterprises creditworthiness substantially expands the components of the creditworthiness level evaluation of enterprises and, as a consequence, improves the timeliness of decision-making process about identifying and locating of weaknesses and "bottlenecks". The coverage of a sufficient number of financial and economic indicators and the implementation of a wide range of methods and models enable to fully evaluate and analyze the existing state of creditworthiness with a view to improve and establish the effective functioning of the enterprise as a whole.

Keywords: diagnostic model, creditworthiness, agrarian enterprises, indicators, multidimensional methods, multi-scale modeling, classification, discriminant analysis, cluster analysis, dispersion analysis.

\section{Introduction}

Nowadays due to the imperfect state of transformational changes in the Ukrainian economy there exists a steady tendency for increasing of the number of financially-insolvent enterprises in various industries; especially it concerns agrarian enterprises [1]. The reason for this is the lack of a proper methodological basis for a complex diagnostics of the financial condition, the level of stability, competitiveness and other components that are very important for any wholly integrated production and economic system (PES), because the inopportune revealing of "bottlenecks" and the lack of response to "Weak signals" generate a flow of crisis financial processes that extend to all areas of any systems' lifecycles [2-4].
\end{abstract}

DOI: $10.21303 / 2504-5571.2019 .001082$ 
First of all the effectiveness of agrarian enterprises is determined by the financial status and level of creditworthiness. Credit and financial institutions assess borrower's creditworthiness, using various methodological approaches. An important contribution to development of assessing the creditworthiness of potential borrowers was made by famous foreign economists, namely E. Brigem, L. Happensky, S. Rose, J. Sinki and others. A considerable attention to the problem of assessing the creditworthiness of potential borrowers also was given in the written works of such Ukrainian scientists as, O. V. Pernarivsky, O. D. Vovchak, O. V. Dzubluk, T. Karapetyan, V. V. Vitlinsky, O. G. Malii, O. O. Tereshchenko, I. Tchaikovsky and others. During the analysis of literary sources about the state of the development of the methodological approaches of diagnosis of enterprises' creditworthiness, we can conclude that the most accepted are the diagnostic models, based on the Altman Z-score, the diagnosis by the model of W. Beaver, the Taffler Z-Score Model, Springate model, and Fulmer's model, and others. But these models are used mostly for determining the propensity of bankruptcy, diagnosing the crisis and the bankruptcy threat and its probability, rather than creditworthiness; hence the problem under consideration cannot be regarded as sufficiently studied. The analysis of the diagnostic models shows that none of them can claim its use as a universal diagnostic technique. Obviously, the choice of certain models and methods should be dictated by the peculiarities of the national economy and industry, but also by the specific features of the activities and external environment, in which the enterprise operates. All this provides the basis for constructing of the diagnostic models of creditworthiness that are appropriate to the domestic conditions of the agrarian enterprises' functioning.

The diagnosis of creditworthiness in the work refers to the assessment, analysis and identification of the state, tendencies and perspectives of activity, based on the system of indicators, which are used in order to form a structured information base, adopt an argumentative management decisions that are aimed at eliminating the problem points and weaknesses of the activity, and also use adequately the existing potential and strong positions of the enterprise $[5,6]$. One of the main areas of diagnostics of agrarian enterprises is the diagnosis of creditworthiness due to the specificity of financially-economic and production activities of the considered enterprises [7,8].

The main aim of this work is to construct a diagnostic model of creditworthiness assessment, based on the use of multidimensional analytical methods (cluster, discriminatory and dispersive), which allows to classify the agrarian enterprises by the level of creditworthiness with taking into account the differentiation by their size on such groups as "large", "medium" and "small". These steps will ensure the objectification of the estimation results for the development of the management solution system for various economic entities, such as creditors and agrarian enterprises.

\section{Materials and Methods}

The object of the research is the financially-economic conditions of 14 agrarian enterprises of Ukraine. Researching of the creditworthiness diagnostic problem of the agrarian enterprises allows to mark out the following tasks [8-10]:

- analysis and synthesis of indicators that reflect the level of creditworthiness of enterprises;

- formation of homogeneous classes of enterprises according to the level of their creditworthiness;

- recognition and identification of enterprises by the level of creditworthiness;

- estimation of differences between classes with taking into account the factor of the enterprises sizes;

- implementation of research results for the development of managerial decisions.

The execution of the listed tasks is carried out, based on the proposed instrumental diagnostic technology of the agrarian enterprises' creditworthiness, the main steps of which are illustrated on the Fig. 1. 


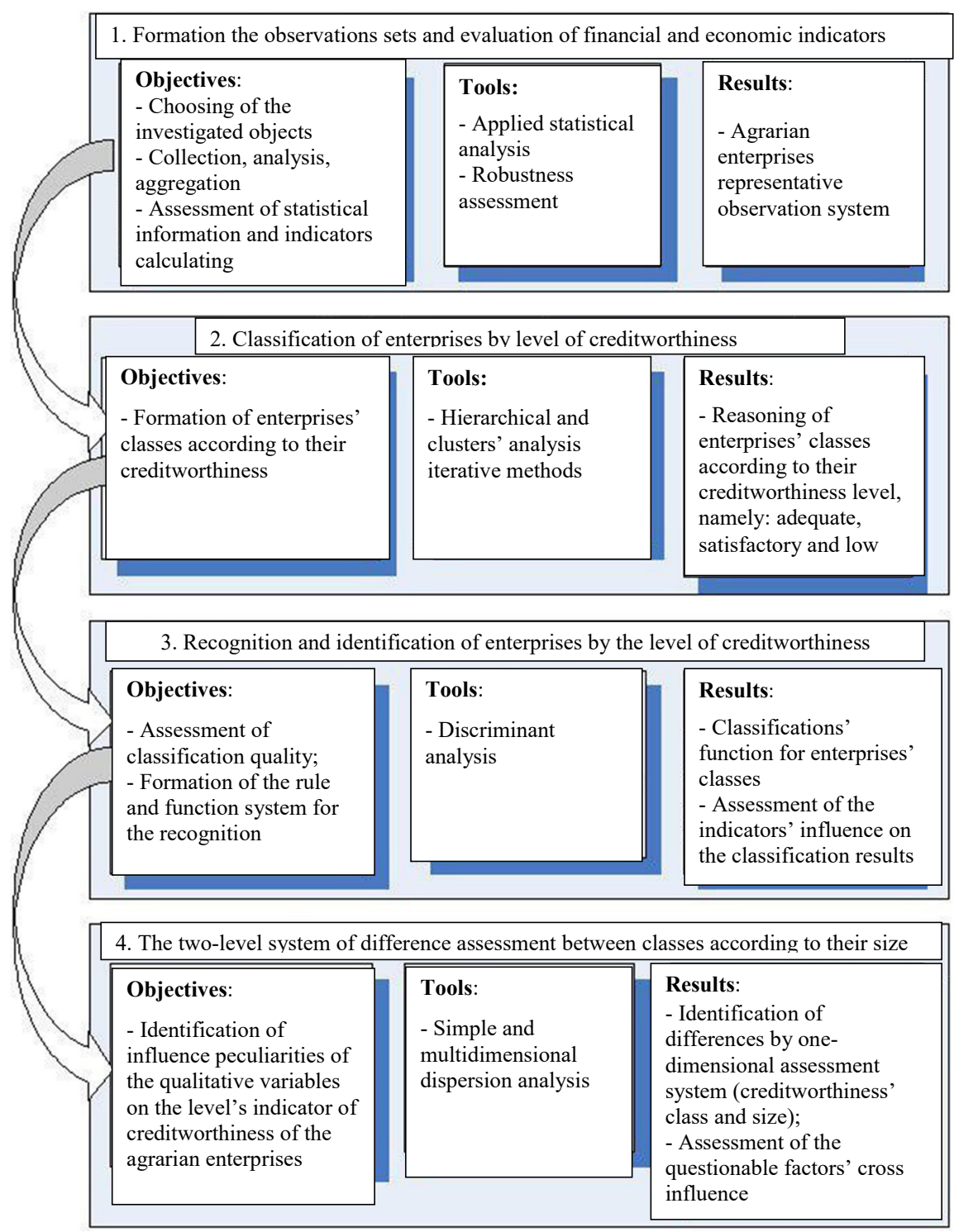

Fig. 1. The main stages of the creditworthiness' diagnosis of agrarian enterprises by the multi-scale modeling

Step 1 - Formation of the observations sets and evaluation of financial and economic indicators.

Step 2 - Classification of enterprises by level of creditworthiness.

Step 3 - Recognition and identification of enterprises by the level of creditworthiness.

Step 4 - The two-level system of difference assessment between classes according to their size.

\section{Results and Discussion}

Let's consider the goals and objectives of each step of the proposed methodically-diagnostic approach.

Step 1 - Formation of a set of observations and evaluation of financial and economic indicators.

The main objectives of this stage are the assessment and analysis of the characteristics of competitive indicators of enterprises and the formation of an indication informative system - indicators $[11,12]$. For the diagnosis, in the work, the assessment indicators of the creditworthiness of agricultural enterprises, which were proposed by the NBU for medium and large enterprises, were 
selected [13]. The methodology is contained in the "Statement about the procedure of the reserves" establishment and use by the Ukrainian banks in order to recover possible losses because of the active banking transactions" [9]. For medium and large agricultural enterprises, the NBU proposes the model of calculating for the integral indicator of a debtor, using a multi-factor discriminant model, which is based on the following coefficients: K3 - coefficient of financial independence; K4 - coefficient of coverage of non-current assets by the own funds; K5 - coefficient of the own funds' profitability; K6 - profitability coefficient of sales, based on financial results from operating activities (Earnings before interest and taxes "EBIT"); K7 - profitability coefficient of sales, based on financial results of ordinary activities ( Earnings before Interest, Taxes, Depreciation and Amortization "EBITDA"); K8 - profitability coefficient of assets by net profit; K9 - turnover coefficient of working capital.

The sample of observations was checked for robustness and representativeness for the 14 agrarian enterprises according to the 7 indicators [14].

Step 2 - Classification of enterprises by level of creditworthiness.

The objective of this phase is to implement a cluster analysis methodology in a comparative context for the formation of similar types of classes by the level of creditworthiness, based on hierarchical and iterative cluster procedures $[15,16]$. The results of the classification of the investigated agrarian enterprises were the Ward's dendrogramm method (Fig. 2) and the graph of the mean values of the clusters' states indicators by the K-medium method were shown in Fig. 3 and constructed in the PPI Statistica $[17,18]$. By the levels of competitiveness and based on the dendrogramm analysis, intraclass and interclass dispersions (Fig. 4), the differences in the clusters' mean values that met the quality criteria of clusterization, there are 3 classes that can be marked out. The dispersion analysis (Fig. 4) is confirmed by the fact that in clusters the variance is rather changeable, and according to some indicators of enterprises, the differences are insignificant and that is made the interpretation of the results more complicated. Talking about the coefficients K8 (profitability coefficient of assets by net profit) and K3 (coefficient of financial independence), the results of clusterization show that these indicators have almost identical average values for enterprises with different levels of creditworthiness.

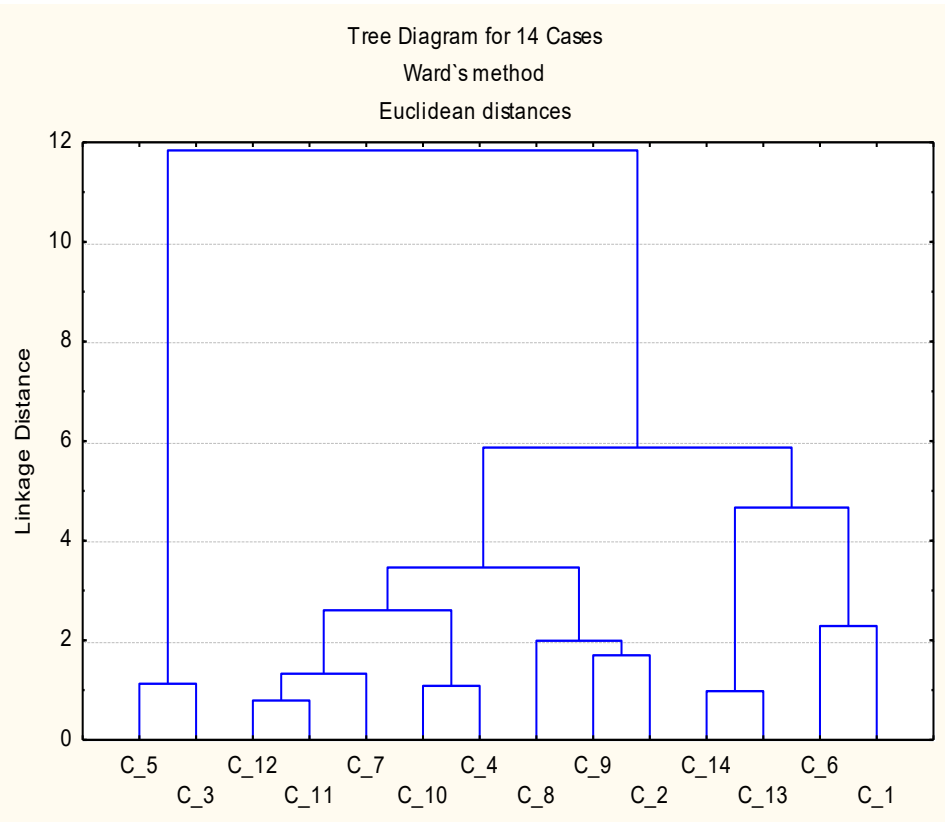

Fig. 2. Ward's method of the agrarian enterprises classification

Judging by the results of the F-criterion, the most significant indicator for the clustering process is K9, which is the turnover coefficient of working capital, because the values of this indicator have the biggest difference among enterprises of various clusters. In general, it can be concluded, that the classification was performed qualitatively. 


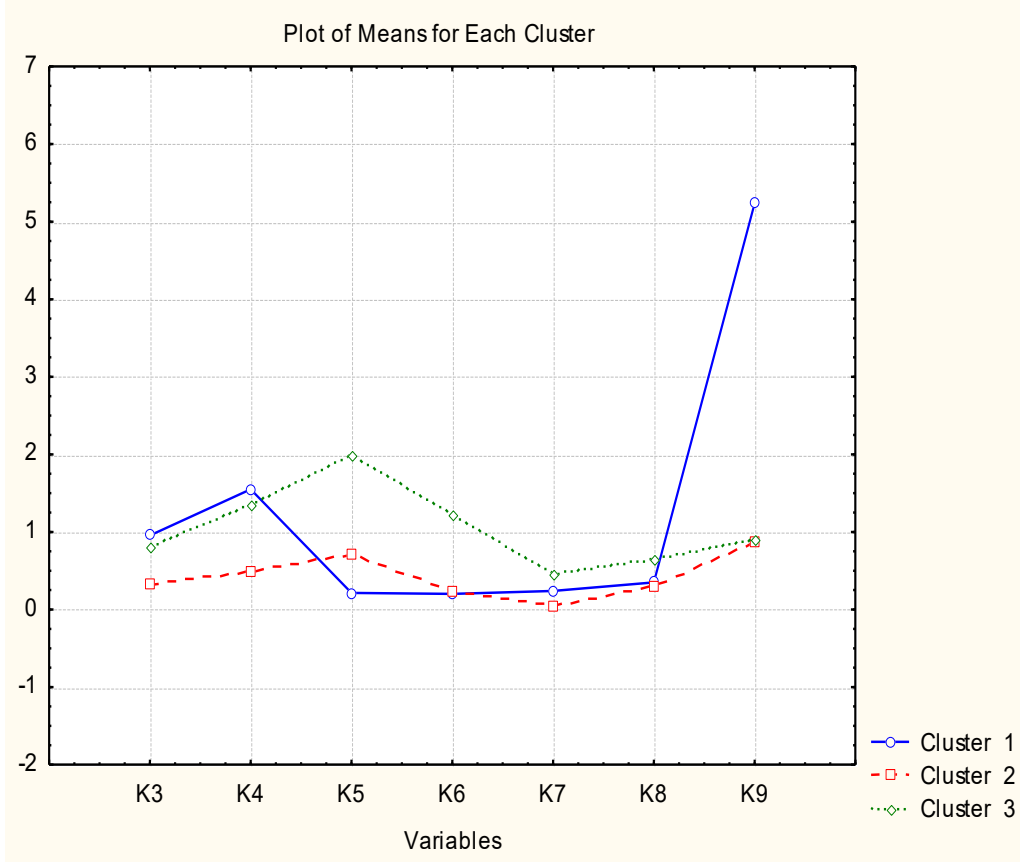

Fig. 3. Graph of the average values of clusters' indicators by the K-means method

\begin{tabular}{|c|c|c|c|c|c|c|}
\hline \multirow[b]{2}{*}{ Variable } & \multicolumn{6}{|c|}{ Analysis of Variance (Spreadsheet1) } \\
\hline & \begin{tabular}{|c|} 
Between \\
SS
\end{tabular} & $\mathrm{df}$ & $\begin{array}{c}\text { Within } \\
\text { SS }\end{array}$ & df & $\mathrm{F}$ & $\begin{array}{c}\underset{p}{\operatorname{signif.}} \\
\mathrm{p}\end{array}$ \\
\hline K3 & 0,9953 ، & 2 & 1,85986 & 11 & 2,9434 & 0,09465 \\
\hline K4 & 2,8993 ، & 2 & 4,58233 & 11 & 3,4799 & 0,06745 \\
\hline K5 & 6,6225 & 2 & 5,30802 & 11 & 6,8620 & 0,01162 \\
\hline K6 & 3,3403: & 2 & 4,61443 & 11 & 3,9813 & 0,05002 \\
\hline K7 & 0,48641 & 2 & 0,89036 & 11 & $3,0046 !$ & 0,09096 \\
\hline K8 & 0,42561 & 2 & 2,594271 & 11 & 0,90231 & 0,43365 \\
\hline K9 & $32,3351:$ & 2 & 4,83366 & 11 & 36,7926 & 0,00001 \\
\hline
\end{tabular}

Fig. 4. Analysis of Variance and Fisher's criterion of the creditworthiness indicators of the agrarian enterprises

So, based on the classification results of the creditworthiness level, the agrarian enterprises can be divided into clusters as follows (Table 1).

Table 1

Distribution of agrarian enterprises by the creditworthiness levels

\begin{tabular}{|c|c|c|}
\hline $\begin{array}{l}\text { Clusters' } \\
\text { number }\end{array}$ & Level of creditworthiness & Characteristics \\
\hline $1^{\text {st }}$ cluster & $\begin{array}{l}\text { Enough level of creditworthiness } \\
\qquad \text { (No. 3, No. 5) }\end{array}$ & $\begin{array}{l}\text { Ventures, that are financially independent, receive a profit from their main } \\
\text { activity and that are able to make a full and on-time payment to coun- } \\
\text { terparties according to the short-term obligations as they have sufficient } \\
\text { turnover of current assets. }\end{array}$ \\
\hline $2^{\text {nd }}$ cluster & $\begin{array}{l}\text { Low level of creditworthiness } \\
\text { (No. } 2 \text {, No. } 4 \text {, No. } 7, \text { No. } 8 \text {, No. } 10 \\
\text { No. } 11, \text { No. } 12 \text { ) }\end{array}$ & $\begin{array}{l}\text { Enterprises with a low level of independence, coverage, turnover and prof- } \\
\text { itability, that are not able to pay off their debts in time and furthermore } \\
\text { that have losses from their main productive activity }\end{array}$ \\
\hline $3^{\text {rd }}$ cluster & $\begin{array}{l}\text { Satisfying level of creditworthiness } \\
\text { (No. } 1 \text {, No. 6, No. 9, No. } 13 \text {, No. } 14 \text { ) }\end{array}$ & $\begin{array}{l}\text { Enterprises with satisfactory profitability level, however with insufficient } \\
\text { coverage and turnover of assets, nevertheless these enterprises can pay their } \\
\text { obligations and restore financial independence in relatively short term }\end{array}$ \\
\hline
\end{tabular}

Distribution of agrarian enterprises by levels of creditworthiness in quantitative and percentage ratios is shown on the Fig. 5 . 


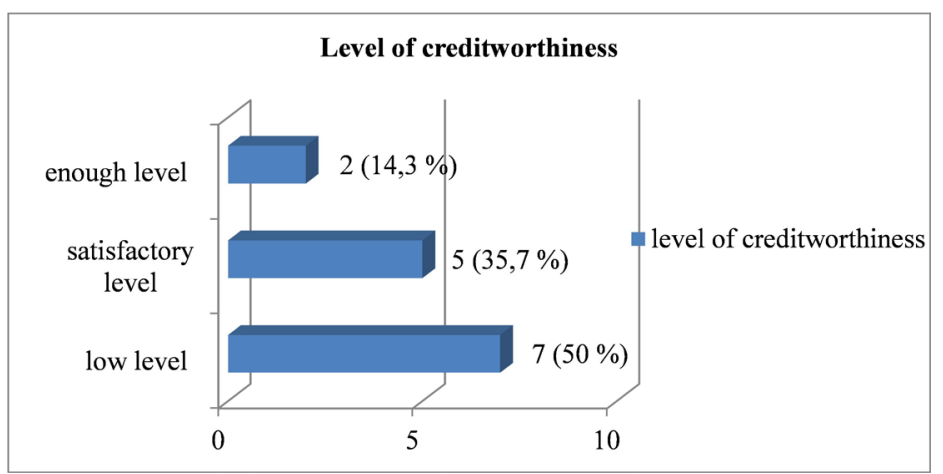

Fig. 5. Distribution of agrarian enterprises by levels of creditworthiness

As a result, we can say that using of the assessment cluster analysis tools for the creditworthiness of agrarian enterprises can solve the following diagnostic objectives:

- analysis of the implementation peculiarities of the financially - economic potential of competitiveness by the identifying of enterprises' homogeneous groups in the agrarian sector, this step makes it possible to identify the weak and strong sides of the enterprise in the established directions within this type of economic activity;

- the data size reducing according to the qualitative features of the three levels of creditworthiness - "sufficient", "satisfactory" and "low" - to justify the boundaries of a multilevel assessment of the financial state indicators' influence on the enterprises' creditworthiness.

Step 3 -Recognition and identification of enterprises by level of creditworthiness.

The focus of this stage is the implementation of discriminatory analysis tools [15, 19-21] for the formation of the rule and classification functions system for identifying enterprises by the level of their creditworthiness and estimating the indicators influence on the classification results. For the construction of an adequate discriminant model, the variables (indicators) selection stage and the verification of multicollinearity presence are very significant steps [22]. Checking the dependence of indicators, based on the regression-correlation analysis [22, 23], can be made by extracting the indicators that have the greatest correlation from the model, and, hence, depriving the existence of multi-collinear variables in it. The matrix of correlations for indicators of competitiveness is shown in Fig. 6.

\begin{tabular}{|c|c|c|c|c|c|c|c|}
\hline & $K 3$ & $K 4$ & $K 5$ & $K 6$ & $K 7$ & $K 8$ & $K 9$ \\
\hline K3 & 1 & & & & & & \\
\hline K4 & 0.531347 & 1 & & & & & \\
\hline K5 & 0.219869 & 0.215229 & 1 & & & & \\
\hline K6 & -0.02483 & -0.25276 & 0.492947 & 1 & & & \\
\hline K7 & 0.496906 & 0.575605 & 0.282819 & 0.040891 & 1 & & \\
\hline K8 & 0.148113 & 0.373077 & 0.013688 & 0.050864 & 0.532946 & 1 & \\
\hline K9 & 0.327189 & 0.409127 & -0.4291 & -0.24508 & -0.01369 & 0.110759 & 1 \\
\hline
\end{tabular}

Fig. 6. Correlation matrix of the creditworthiness coefficients

Checking the indicators for the multicollinearity presence by the Ferrar-Globe criterion $[22,24]$ proves the absence of close linear relationships between the studied variables, thus, it states the lack of multicollinearity and the practicability of using the entire bundle of variables for the classification functions construction.

Key features of the discriminant analysis model of the agrarian enterprises creditworthiness recognition are shown on the Fig. 7.

The analysis of discriminant functions that were created in Statistica confirms the quality of the constructed model and influence degree of the input variables on the final result of the classification. The value of Lambda Wilkes (Wilk's Lambda) is close to zero (Wilk's Lambda =0.00610), that means the perfect quality of discrimination. From the analysis, it is clear, that the indicators K6 and $\mathrm{K} 9$ give the most significant contribution to the discriminant function, because they have the 
highest value according to Fisher's criterion. The system of discriminatory classification functions has the following form:

$$
\left\{\begin{array}{l}
Z_{1}=-73,39+2,55 \cdot K_{3}+6,21 \cdot K_{4}+3,52 \cdot K_{5}+16,17 \cdot K_{6}+37,43 \cdot K_{7}-19,15 \cdot K_{8}+23,79 \cdot K_{9} \\
Z_{2}=-4,86+1,56 \cdot K_{3}+3,78 \cdot K_{4}+2,24 \cdot K_{5}+5,96 \cdot K_{6}+5,73 \cdot K_{7}-0,49 \cdot K_{8}+3,27 \cdot K_{9} \\
Z_{1}=-40,12+3,39 \cdot K_{3}+17,24 \cdot K_{4}+5,11 \cdot K_{5}+23,59 \cdot K_{6}+19,71 \cdot K_{7}-0,24 \cdot K_{8}+4,45 \cdot K_{9} .
\end{array}\right.
$$

\begin{tabular}{|c|c|c|c|c|c|c|}
\hline \multirow[b]{2}{*}{$N=14$} & \multicolumn{6}{|c|}{$\begin{array}{l}\text { Discrim inant Function Analysis Summary (Spreadsheet1) } \\
\text { No. of vars in model: } 7 \text {; Grouping }(3 \text { grps) } \\
\text { Wilks' Lam bda: ,00610 approx. } F(14,10)=8,4330 \mathrm{p}<, 0009\end{array}$} \\
\hline & $\begin{array}{c}\text { Wilks' } \\
\text { Lambda }\end{array}$ & $\begin{array}{l}\text { Partial } \\
\text { Lambda }\end{array}$ & $\begin{array}{c}\text { F-rem ove } \\
(2,5)\end{array}$ & p-level & Toler. & $\begin{array}{l}\text { 1-Toler. } \\
\text { (R-Sqr.) }\end{array}$ \\
\hline $\mathrm{K} 3$ & 0,00615 & 0,99017 & 0,0248 & 0,975611 & 0,75446 & 0,24553 \\
\hline $\mathrm{K} 4$ & 0,01107 & 0,55068 & $2,0397^{\circ}$ & 0,22504 & 0,24415 & 0,75584 \\
\hline$K 5$ & 0,00656 & 0,92953 & 0,1 & 0,83302 & 0,76587 & 412 \\
\hline K6 & 0,02241 & 0,27204 & 6,6895 & 0,03860 & 0,24158 & 0,75841 \\
\hline K7 & 0,00964 & 0,63201 & 1,4556 & 0,31755 & 0,41421 & 0,58578 \\
\hline K8 & 0,01005 & 0,60627 & 1,6235 & 0,28620 & 0,43275 & 0,56725 \\
\hline $\mathrm{K} 9$ & 0,04472 & 0,13634 & 15,8363 & 0,00686 & 0,45128 & 0,54871 \\
\hline
\end{tabular}

Fig. 7. Discriminant function analysis summary

In order to select the most important factors of each credits classes, an assessment of individual indicators' influence on the results of discriminatory analysis was performed. The influence of the indicators on the variation dimension of the dependent variable (discriminant function) can be calculated by the following formula $[10,25]$ :

$$
R_{K_{j}}=\frac{\left|a_{j}^{*}\right|}{\sum_{j=1}^{m}\left|a_{j}^{*}\right|} \cdot 100 \%
$$

where $R_{K_{j}}$ - values of influence of the $j(\%)$ factor variable $\left(K_{j}\right)$ to the dependent variable; $\left|a_{j}^{*}\right|-$ module of indicator value $\left(K_{j}\right)$.

Thus, the range of variation of the dependent variable depends on $R_{K_{j}}$ percent from the $K_{\mathrm{j}}$-th independent variable. The rest of the independent variables accounts for $100 \% R_{\kappa_{j}}$ of the Y variation [26]. The calculating results about the influence of the studied indicators on the value of the discriminant function for each selected creditworthiness class are shown in Table 2.

Table 2

Estimation of the financial indicators influence to the discriminant function value for the agrarian enterprises (\%)

\begin{tabular}{cccc}
\hline Indicators & $\begin{array}{c}\text { I cluster } \\
\text { Enough level of creditworthiness }\end{array}$ & $\begin{array}{c}\text { II cluster } \\
\text { Low level of creditworthiness }\end{array}$ & $\begin{array}{c}\text { III cluster } \\
\text { Satisfactory level of creditworthiness }\end{array}$ \\
\hline$K_{3}$ & 2.34 & 6.77 & 4.60 \\
$K_{4}$ & 5.71 & 16.41 & 23.38 \\
$K_{5}$ & 3.23 & 9.73 & 6.93 \\
$K_{6}$ & 14.86 & 25.88 & 32.00 \\
$K_{7}$ & 34.40 & 24.88 & 26.73 \\
$K_{8}$ & 17.60 & 2.13 & 0.33 \\
$K_{9}$ & 21.86 & 14.20 & 6.04
\end{tabular}

Thereby, the greatest influence of the variable K7 - profitability coefficient of sales, based on financial results of ordinary activities ( Earnings before Interest, Taxes, Depreciation and Amortization "EBITDA"), is observed for enterprises with enough level of creditworthiness, 
and the variable K6 - profitability coefficient of sales, based on financial results from operating activities (Earnings before interest and taxes "EBIT"), has the biggest impact on the value of discriminatory functions for enterprises with a low and satisfactory level of creditworthiness. Also it should be noted, that the influence of factors completely coincides for enterprises of II and III classes.

With the help of visual analysis, based on the scattering plot of enterprises in the space of discriminatory roots, the quality of recognition and identification can either be determined (Fig. 8).

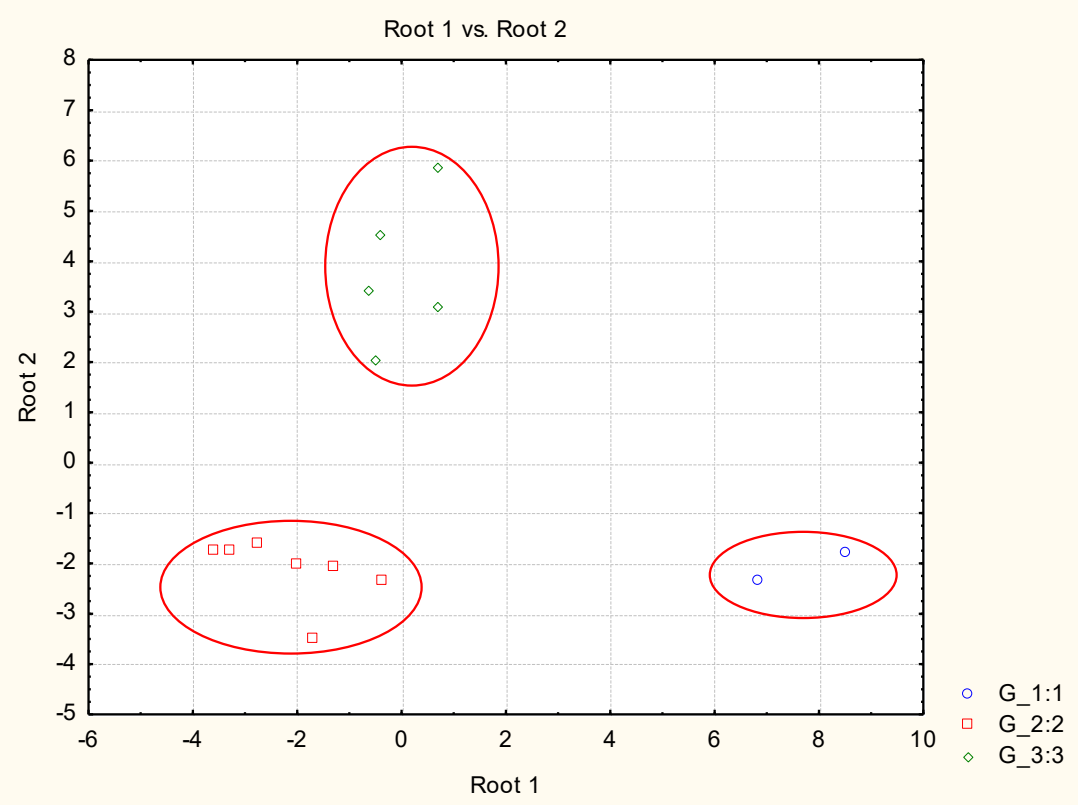

Fig. 8. Scatterplot of agrarian enterprises in the space of discriminatory roots by three clusters

The graph shows that the objects are grouped quite densely in the three classes, and the distances between the clusters are rather long. This will allow proving with higher probability that the recognition of enterprises by the three classes of creditworthiness was performed in the right way. On the basis of the constructed discriminatory functions, the creditworthiness class and the forecasting recognition of its level were carried out for both the investigated and prospect period. their size.

Step 4 - The two-level system of difference assessment between classes according to

At this stage, the investigation of the indicators' variability of the agrarian enterprises creditworthiness has been conducted, that includes the comparing of the indicators' level, that depends on the values of the discriminatory function, and the enterprises' sizes, using dispersion analysis methods $[16,20]$ for the evaluation of the differences between the studied creditworthiness' classes.

The Fig. 9, 10 show graphs of differences in the discriminatory function's values according to the creditworthiness' levels and agrarian enterprises dimensionality; based on the calculation results, the causative interrelation between the creditworthiness' indicators has been established, and it has allowed to make the following conclusions.

1) The lowest values of the discriminatory function have the enterprises of the 2 nd cluster (low creditworthiness), while the highest positive values are common for the 1st cluster with enough level of creditworthiness.

2) The differences in the meaning of the discriminatory function are also revealed, with taking into account the sizes of enterprises that means that the highest values of the discriminatory function are common for medium enterprises, and the lowest values - for large ones. 
3) The cross two-aspect assessment by the level of creditworthiness and size of enterprises or by the size of enterprises and the level of creditworthiness (Fig. 10) shows the existence of significant differences in the received 9 different classes, but correspondence with the general level of creditworthiness.
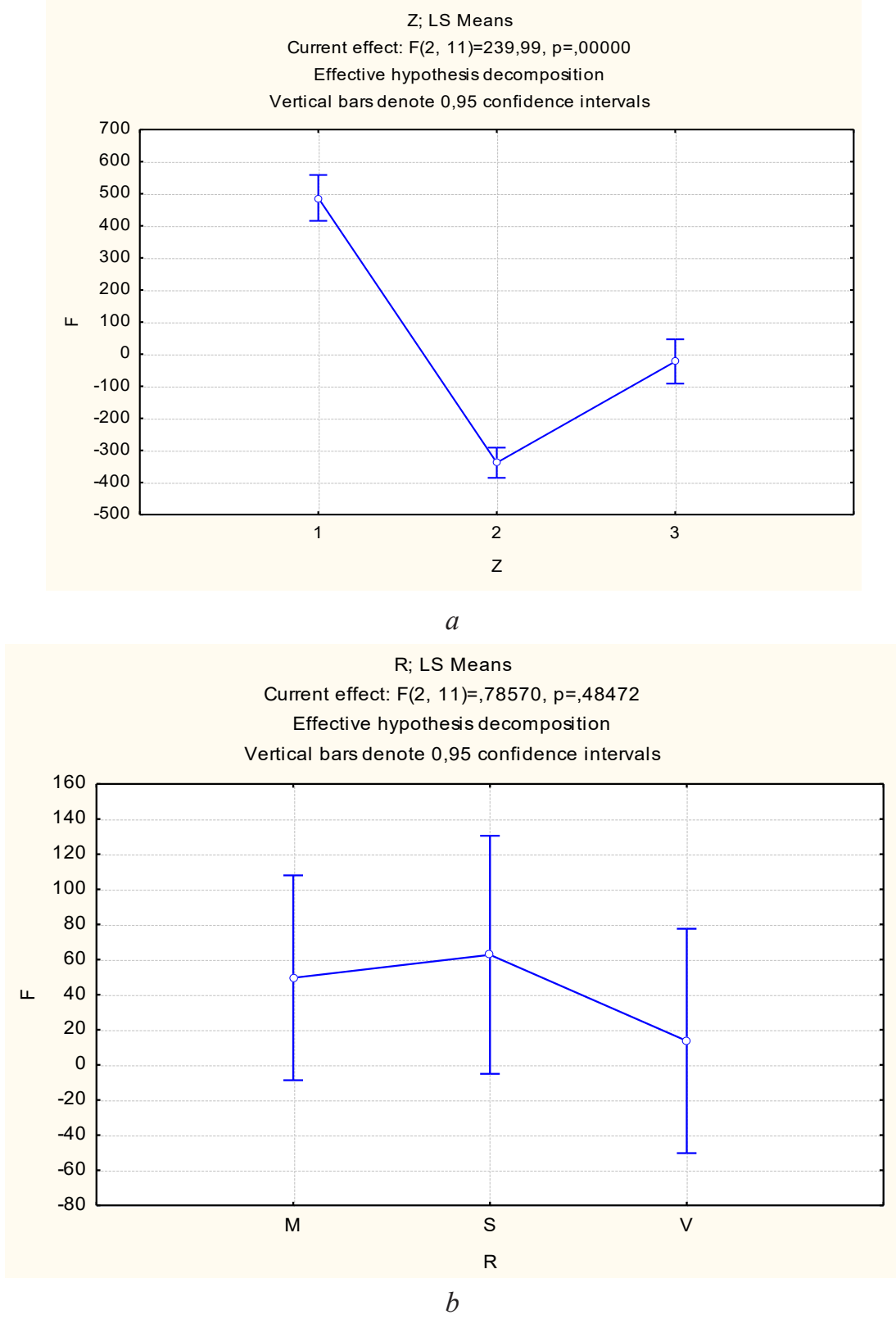

Fig. 9. Graphs of creditworthiness' differences between classes by dispersion analysis methods: $a$-difference in the discriminatory function according to the level of creditworthiness of the agrarian enterprises; $b$ - Difference in the discriminatory function according to the sizes of the agrarian enterprises

Using of the dispersion analysis methods in the investigation of the agrarian enterprises creditworthiness enabled to determine the nature of the differences for their researched aggregate and to test the hypothesis about the factors' influence with their interrelation to the corresponding level of significance. The result is an evaluation of the creditworthiness indicators' variability of the agrarian enterprises, resulted from the influence of each researched independent variables, the interaction of their totality, and the random factors. 
$Z^{*} \mathrm{R}$; Unweighted Means

Current effect: $F(1,8)=69,2018, p=, 023433$

Effective hypothesis decomposition

Vertical bars denote 0,95 confidence intervals

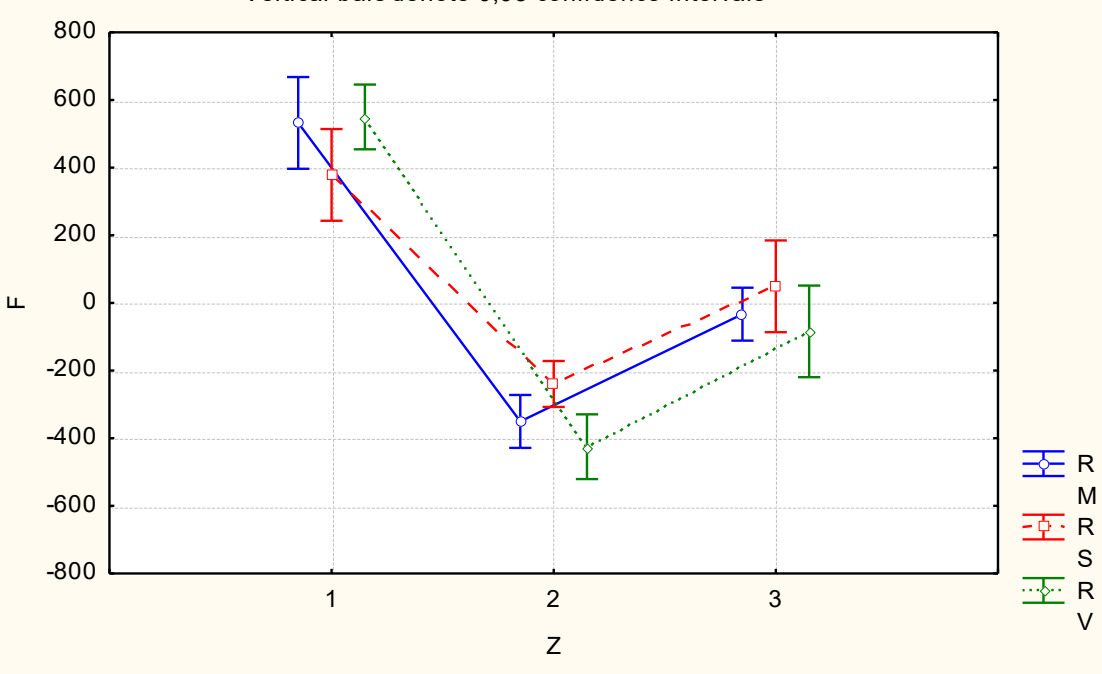

$a$

$Z^{\star} R$; LS Means

Current effect: $F(1,8)=69,2018, p=, 023433$

Effective hypothesis decomposition

Vertical bars denote 0,95 confidence intervals

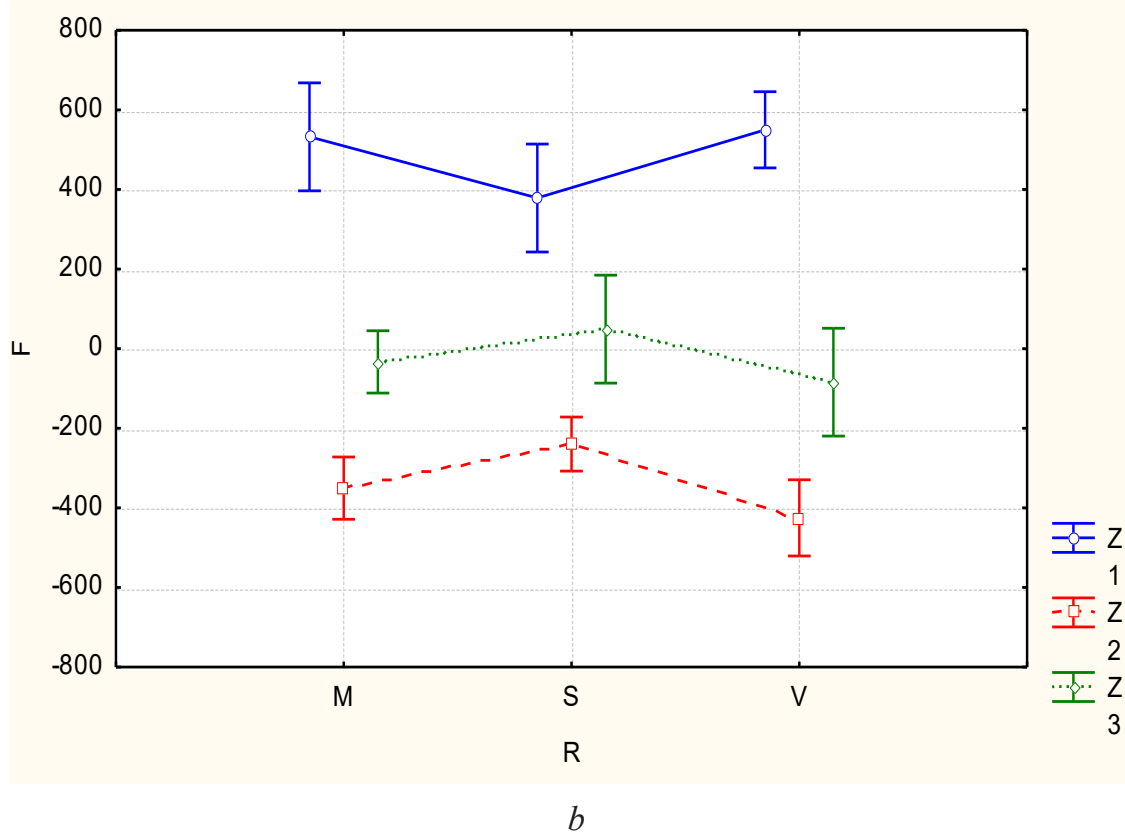

Fig. 10. Graphs of two-level system creditworthiness' differences between classes by dispersion analysis methods: $a$-cross two-aspect analysis by the level of creditworthiness and sizes of agrarian enterprises; $b$ - cross two-aspect analysis by the sizes and level of creditworthiness of agrarian enterprises

\section{Conclusions}

Unlike the already existing methods, the developed adapted methodological approach for the diagnosis of borrower's creditworthiness of agrarian enterprises, is based on a combination of multidimensional analysis methods (discriminatory, cluster and dispersive), which allows to clas- 
sify enterprises by the creditworthiness level, with taking into account the differentiation by size on such groups of enterprises, as "large", "medium" and "small". This allows to objectivize the results of diagnostics and to form the management decision-making system for different business entities, namely credit institutions and agrarian enterprises. Initiation of this diagnostic technology in practice of business entities will allow:

- to diagnose the set of different creditworthiness states and to define their features;

- to forecast the trajectory of enterprise behavior and to identify "bottlenecks" in the activities of agrarian enterprises in order to increase the level of creditworthiness;

- to develop measures to prevent and avoid the creditworthiness level reduction and discouraging of bankruptcy threats.

The proposed four-step technology for diagnosing of the agrarian enterprises creditworthiness substantially expands the components of the creditworthiness level evaluation of enterprises and, as a consequence, improves the timeliness of decision-making process about identifying and locating of weaknesses and "bottlenecks". The coverage of a sufficient number of financial and economic indicators and the implementation of a wide range of methods and models enable to fully evaluate and analyze the existing state of creditworthiness with a view to improve and establish the effective functioning of the enterprise as a whole.

The presented diagnostics model of agricultural sector enterprises is quite comprehensive and encompasses a wide range of activities as it provides a solution of the evaluation, analysis and monitoring of company creditability by the universal set of financial and economic indicators and can be the basis for the formation and selection of different entities operational scenarios, based on hierarchical evaluation in order to implement informed decisions to manage enterprises creditworthiness in any industry.

\section{References}

[1] Martinchik, O. A. (2014). Ocinka konkurentnogo seredovischa silskogospodarskikh pidpriemstv Zhitomirskoi oblasti. BiznesInform, 7, 149-153.

[2] Hula, A. (2015). Credit rating of agricultural enterprises. Ekonomika rozvytku, 4 (182), 55-61.

[3] Smovzhenko, T. S., Azarenkova, G. M. et. al.; Kuznecovoi, A. Ia. (Ed.) (2014). Sovremennoe sostoianie i problemy razvitiia biznesa. Kiev: UBS NBU, 306.

[4] Yatsiv, I. B. (2013). Konkurentospromozhnist silskohospodarskykh pidpryiemstv. Lviv: Ukrainskyi bestseler, 427.

[5] Burlan, S. A., Filimonova, O. B. (2007). Metodolohichni aspekty otsinky kredytospromozhnosti pidpryiemstv ahrarnoho vyrobnytstva. Naukovi pratsi, 64 (51), 71-76.

[6] Kravchenko, E. N. (2016). Diagnostika deiatelnosti predpriiatii kak ocenka effektivnosti khoziaistvennoi i finansovoi deiatelnosti v usloviiakh krizisa. Ekonomicheskie nauki, 58-1. Available at: https://novainfo.ru/article/10183

[7] Nepochatenko, O. O., Chekaliuk, S. A. (2015). Konkurentospromozhnist silskohospodarskykh pidpryiemstv Ukrainy. Ekonomika APK, 7, 41-46.

[8] Zabrodskii, V. A., Kizim, N. A. (2003). Ocenka i diagnostika finansovogo sostoianiia predpriiatiia. Kharkiv: INZHEK, 121.

[9] Sergienko, E. A. (2007). Kompleks modelei diagnostiki finansovo - ekonomicheskoi deiatelnosti predpriiatiia. BiznesInform, $12(3), 62-68$.

[10] Chaikovskyi, Ya. (2003). Udoskonalennia metodyky kompleksnoi otsinky kredytospromozhnosti pozychalnyka. Visnyk NBU, $11,30-34$.

[11] Rozrakhunok finansovykh koefitsiientiv, shcho vykorystovuiutsia dlia rozrakhunku intehralnoho pokaznyka finansovoho stanu borzhnyka - yurydychnoi osoby. Available at: https://helpiks.org/8-2483.html

[12] Hubenko, V. I. (2010). Konkurentospromozhnist produktsii APK: stan ta mozhlyvosti v umovakh hlobalizatsii. Visnyk Sumskoho natsionalnoho ahrarnoho universytetu. Seriia: «Ekonomika ta menedzhment», 5 (2), 3-7.

[13] Pro zatverdzhennia Polozhennia pro poriadok formuvannia ta vykorystannia bankamy Ukrainy rezerviv dlia vidshkoduvannia mozhlyvykh vtrat za aktyvnymy bankivskymy operatsiiamy: postanova Pravlinnia natsionalnoho banku Ukrainy No. 23. 25.01.2012. Available at: https://zakon.rada.gov.ua/laws/main/z0231-12

[14] Malii, O. H. (2004). Kredytospromozhnist pozychalnyka: osoblyvosti ahrarnoi sfery. Ekonomika APK, 5, 89-98.

[15] Ponomarenko, V. S., Klebanovoi, T. S., Kizima, N. A. (Eds.) (2013). Modeli ocenki i analiza slozhnykh socialno-ekonomicheskikh sistem. Kharkiv: ID «INZHEK», 659. 
[16] Dubina, I. N. (2010). Matematiko-statisticheskie metody v empiricheskikh socialno-ekonomicheskikh issledovaniiakh. Moscow: Finansy i statistika; Infra-M, 416.

[17] Elektronnii uchebnik StatSoft. Available at: http://statsoft.ru/resources/statistica_text_book.php

[18] STATSOFT. Available at: http://statsoft.ru/

[19] Klebanova, T. S., Hurianova, L. S., Chahovets, L. O. et. al. (2018). Biznes-analityka bahatovymirnykh protsesiv. Kharkiv: KhNEU im. S. Kuznetsia, 272.

[20] Simchera, V. M. (2008). Metody mnogomernogo analiza statisticheskikh dannykh. Moscow: Finansy i statistika, 400.

[21] Tereshchenko, O. (2003). Dyskryminantnyi analiz v otsintsi kredytospromozhnosti pidpryiemstva. Visnyk NBU, 6, $24-27$.

[22] Hurianova, L. S., Klebanova, T. S., Serhiienko, O. A. et. al. (2015). Ekonometryka. Kharkiv: KhNEU im. S. Kuznetsia, 384.

[23] Tiurin, Iu. N., Makarov, A. A. (2014). Analiz dannykh na kompiutere. Moscow: MCNMO, 67.

[24] Klebanova, T. S., Kurzenev, V. A., Naumov, V. N. et. al. (2012). Metody i modeli prognozirovaniia socialno-ekonomicheskikh processov. Saint Petersburg: Izd. SZIU RANKH i GS, 566.

[25] Klebanova, T. S., Serhiienko, O. A. (2010). Modelnyi instrumentalnyi bazys stratehichnoho rozvytku vyrobnycho-ekonomichnykh system. Ekonomichna kibernetyka, 1-3 (61-63), 10-20.

[26] Nivorozhkina, L. I., Arzhenovskii, S. V. (2009). Mnogomernye statisticheskie metody v ekonomike. Moscow: Izdatelsko-torgovaia korporaciia «Dashkov i K»; Rostov na Donu: Nauka-Spektr, 224. 